\title{
Retail warehouse performance
}

Received (in revised form): 16 July 2003

\section{Stuart Morley}

is a partner and head of research at GVA Grimley, one of the UK's largest property advisers. The research team cover all aspects of the property market, with a particular emphasis on retail and leisure capacity and impact studies.

\section{Abstract}

Strong retail warehouse rental growth and investment return performance has been evident for much of the last decade. Currently, retail warehouse rental growth is higher than for any other sector and retail warehouse net investment is exceptionally strong. This paper examines the underlying causes of such strong performance both in terms of demand and supply. It looks at forecasts for key economic demand variables over the next few years and how that will affect rental growth and investment returns. This paper is an edited and updated version of a paper given at a Henry Stewart Conference in March 2003, 'Maintaining and Increasing Values in Out of Town Retail'.

\section{Keywords:}

GDP, retail sales, consumer expenditure, house price inflation, retail price deflation, bulky goods sales growth, consumer debt, savings ratio, taxation, equity withdrawal, new construction orders, planning policies

\section{INTRODUCTION}

Once again the retail warehouse sector is the best performing property sector. The Investment Property Databank (IPD) monthly index for May shows year on year rental growth of 3.8 per cent for retail warehouses, 2.3 per cent for all retail, 0.4 per cent for industrial and -7.2 per cent for offices. ${ }^{1}$ Over the last three months, annualised rental growth for retail warehouses has been 4.4 per cent. A similar picture of relatively strong retail warehouse rental performance has been evident for much of the last decade. Even in the recession of the early 1990s, when rental growth was negative in the three main sectors, it remained positive for retail warehouses. As a consequence institutional investment in retail warehouses, as measured by IPD, has increased enormously, from 6.5 per cent of gross investment ten years ago to 27.4 per cent in $2002 .^{2}$ As a percentage of net investment the figures are even more impressive. Total net investment in property was $£ 818 \mathrm{~m}$ in 2002 , but net investment in retail warehouses was $£ 929 \mathrm{~m}, 114$ per cent of the total! In 1992 the equivalent figure was 13 per cent of total net investment.

Over the last 12 months, when office and industrial rental growth 


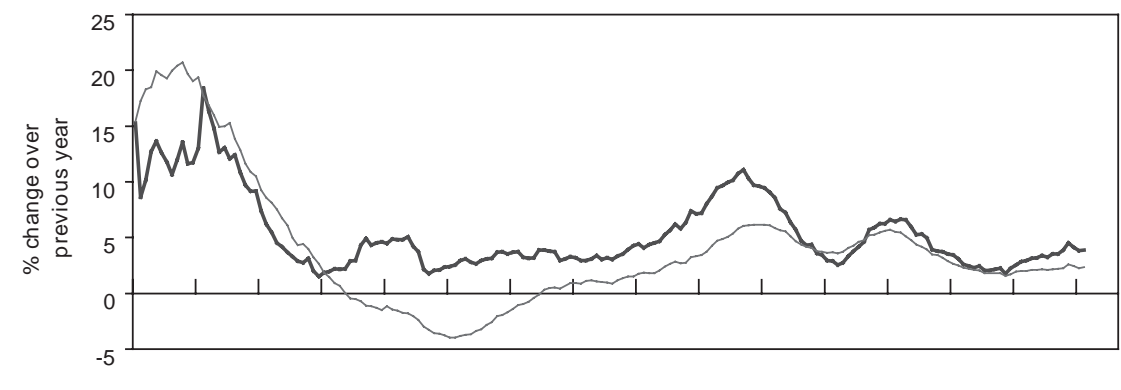

May- May- May- May- May- May- May- May- May- May- May- May- May- May- May- May$\begin{array}{llllllllllllllll}88 & 89 & 90 & 91 & 92 & 93 & 94 & 95 & 96 & 97 & 98 & 99 & 00 & 01 & 02 & 03\end{array}$

Source: IPD

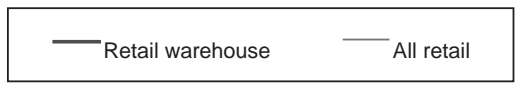

Figure 1: Retail rental growth

has continued to weaken, and retail rental growth has been flat, retail warehouse rental growth has improved noticeably. The bottom of the last cycle was in March 2002 for retail warehousing, when year-on-year rental growth was 1.75 per cent per annum. A year later, in March 2003, rental growth had improved consistently to 4.5 per cent. This suggests the next upswing is well under way, and investment in retail warehouses reflects this. According to Property Data, in the first five months of 2003 retail warehouse purchases totalled a massive $£ 1.8 \mathrm{bn}$, compared to half this in the first half of 2001 and a quarter of this in the first half of $1999 .^{3}$ The retail warehouse sector appears to be booming and is currently 'flavour of the month'. For how much longer can this continue? Will demand/supply imbalances continue indefinitely to underpin such impressive growth? This paper examines the outlook over the medium term (five years) for rental growth and investment returns.

\section{OCCUPATIONAL DEMAND}

The standard economic variables which are generally assumed to drive retail demand are retail sales volume growth, consumer

Economic and rental growth relationship expenditure growth and, to a lesser extent, GDP growth. These variables, together with retail warehouse rental growth (in real terms), are shown in Figure 2. Over much of this 19-year period there has been a reasonably close, but far from perfect, correlation between these key variables and rental growth. But, ever since 1999 this relationship appears to have broken down. A couple of points relating to the last three years are clear:

- the divergence of retail and consumer expenditure growth from GDP growth

- the divergence of retail warehouse rental growth from retail sales and consumer expenditure growth and a closer fit with GDP growth. 


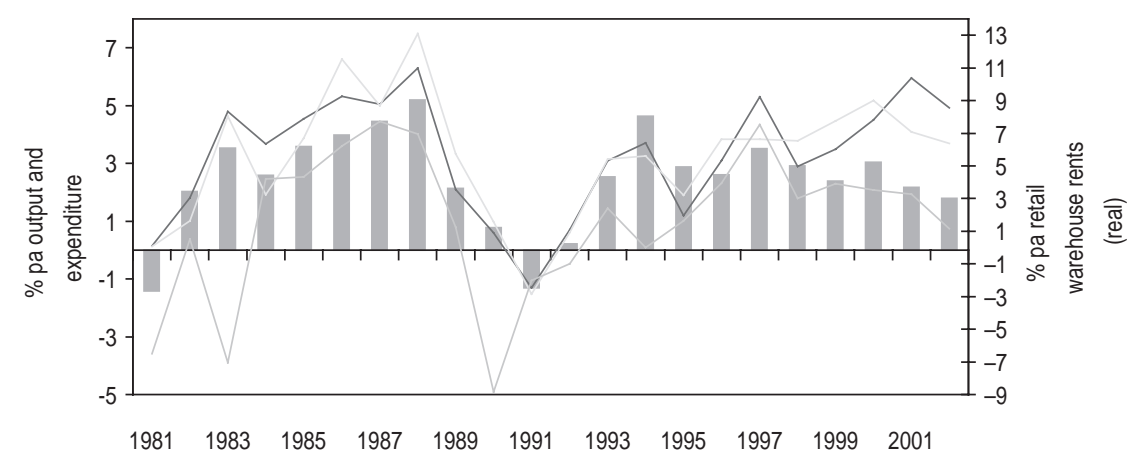

\section{Strong retail expenditure growth}

Source: ONS, EBS, IPD, GVA Grimley

Figure 2: GDP, consumer expenditure, retail sales and retail rents

The explanation for the first point helps explain the second point. Retail (and consumer) expenditure has been strong in recent years due to a number of factors. Low interest rates have increased consumers' ability and desire to borrow and spend. They have also boosted the housing market, stimulating strong house price inflation and hence remortgaging and equity withdrawal, which has increased spending. Another important factor is strong competition among retailers and price deflation, which has further stimulated spending.

It is this latter point which helps explain why retail warehouse rental growth has not been as strong as retail sales volume growth would have suggested. Due to price deflation, retailers' profits have

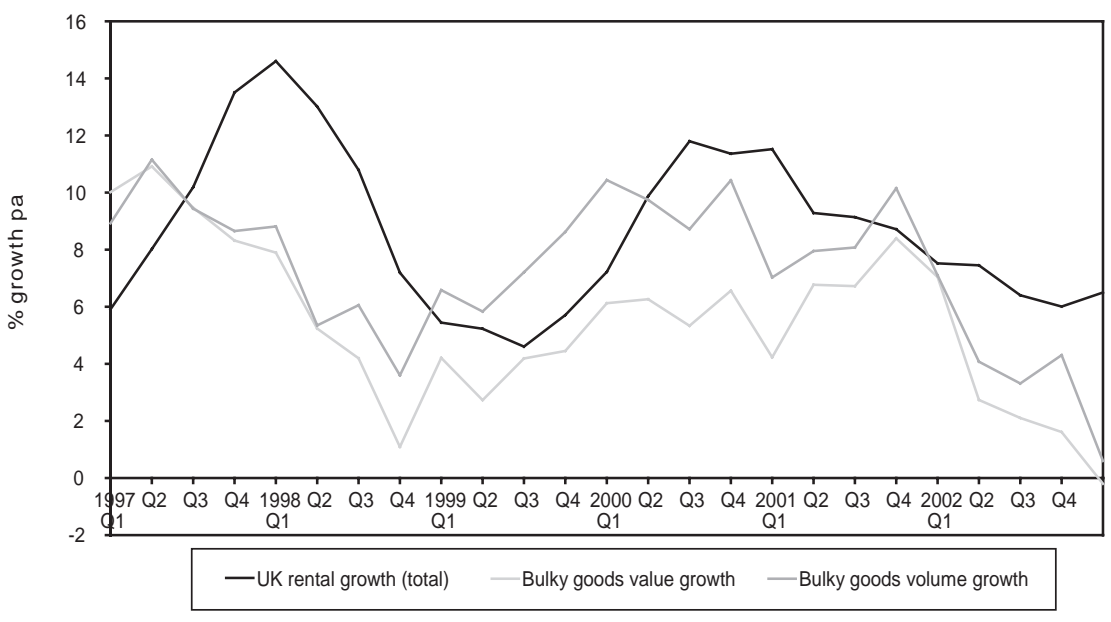

Source: ONS,GVA Grimley

Bulky goods source: ONS data on floor coverings; electrical household appliances; furniture, lighting etc; hardware, paint and glass

Figure 3: GVA Grimley retail warehouse rental index and bulky goods value and volume growth 


\section{Expenditure growth slowing}

\section{Reasons for expenditure growth slowdown}

grown more slowly and that has fed through to weaker demand for space (and rental growth) than retail sales volume growth would suggest.

Other factors of relevance are a growing polarisation between the prime end of the retail warehouse market and the remainder, and differences between bulky goods sales volume growth and total retail sales volume growth. There is a much better fit over recent years, as one might expect, between bulky goods sales volume growth and prime retail warehouse rental growth, as Figure 3 shows.

\section{DEMAND FORECASTS}

Over the last three years retail sales volume growth has averaged 5.4 per cent per annum, non-food sales volume growth has averaged 7 per cent and bulky goods sales volume growth has averaged 8.3 per cent. In contrast, retail warehouse rental growth has averaged just 1.3 per cent in real terms but prime rental growth has averaged 5.7 per cent per annum in nominal terms. ${ }^{4}$ If over the next few years retail sales volume growth slows, as it has already started to do and will almost certainly continue to do, this must affect retail warehouse rental growth.

Why should retail sales volume growth continue to slow, and to what extent will it continue to slow? There are many reasons that are likely to underpin a lengthy slowdown.

First, the last few years have been exceptional, as Figure 2 showed. This divergence between retail sales volume growth and GDP growth cannot continue indefinitely.

Secondly, GDP growth is likely to remain weak in 2003 and only improve slightly in 2004 and subsequent years. The war with Iraq was obviously one factor, but there are other more important underlying factors, such as the after-effects of the boom in the late 1990s, weak business investment, weak global economic growth, a high exchange rate, etc.

Thirdly, consumer debt levels are high and saving ratios are very low. While interest rates remain so low, this may continue, but sooner or later interest rates will increase from their historic low and consumers will adjust their spending accordingly.

Fourthly, National Insurance increases and other measures announced in last year's Budget, plus council tax increases, will affect consumer confidence and expenditure.

Fifthly, the slowdown in the housing market on top of the weak stock market will affect consumers' perception of wealth and their willingness to spend, financed by equity withdrawal or increased borrowing. The housing market slowdown and the likelihood of weak house price inflation over the next few years (but not a crash) will adversely affect bulky goods sales volume growth, more so than comparison goods in total or convenience goods.

Sixthly, the rental advantage of locating on the edge or out of centre is eroding. 
No retail development boom

\section{Restricted retail warehouse supply}

The figures for consumer expenditure growth illustrate the magnitude of the expected spending slowdown very clearly. Over the last four years growth has varied between 3.7 per cent and 5.1 per cent, averaging 4.4 per cent per annum. Over the next four years the range expected by Experian Business Strategies is 2.2 per cent (2003) to 3.1 per cent, averaging 2.6 per cent per annum. ${ }^{5}$ This marked weakening suggests a similar slowdown in retail warehouse rental growth, but that ignores the supply side of the equation.

\section{SUPPLY}

Figure 4 illustrates supply trends over the last two decades. For the retail sector as a whole, the Department of Trade and Industry (DTI) new construction order figures ${ }^{6}$ (constant prices) show an upward trend, as would be expected with retail expenditure growth averaging 2.5 per cent per annum over this period. The chart also shows the marked development boom and subsequent slump in the late 1980s/early 1990s, resulting from the economic and property market boom/recession of that time.

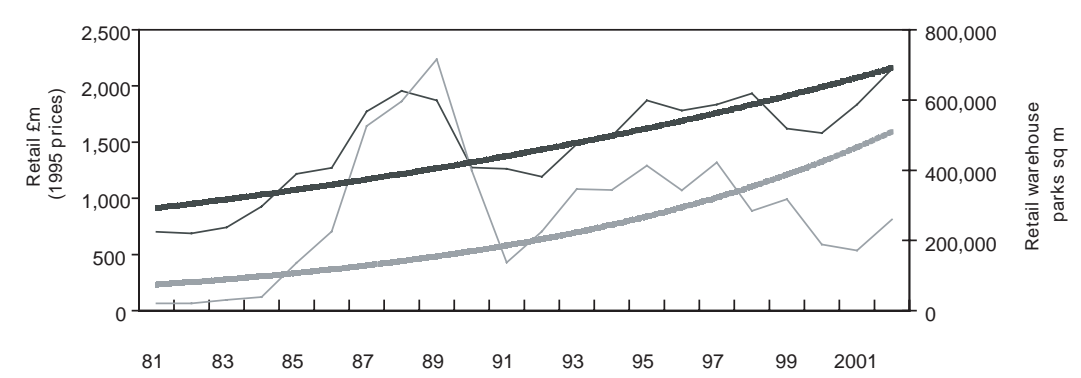

\begin{tabular}{|ll|}
\hline Retail (left-hand axis) & Retail warehouse parks (right-hand axis) \\
Trend (retail warehouse parks) & Trend (retail) \\
\hline
\end{tabular}

Source: DTI, GVA Grimley, CCRE

Figure 4: Retail new construction orders and retail warehouse park development

Over the last decade, in marked contrast to the previous decade, total retail development activity has been more stable and remained fairly close to trend. In recent years development activity has been weaker than might have been expected, but has increased over the last two years to reach the trend line in 2002.

The figures for retail warehousing (unfortunately data are only available for retail warehouse parks) show a similar picture up to the late 1990s, but a marked divergence in recent years. The amount of space completed in recent years has more than halved since the mid-1990s and is now well below the trend line. Undoubtedly this can be explained by restrictive planning legislation (PPG6 of June 1996 and subsequent ministerial statements and appeal/call-in decisions) where out-of-centre and edge-of-centre retail warehouse schemes have been refused planning 


\section{Weaker rental growth expected}

\section{Huge increase in retail warehouse investment}

\section{Downward movement in yields}

permission as they have been seen to threaten town centres. Although quantitative capacity arguments often support more bulky goods retail warehouse development, increased emphasis on the class of goods (disaggregation) rather than a format-driven approach make it even harder to achieve permission for retail warehouse schemes. This trend is unlikely to be reversed, so supplyside constraints will offset, to some extent at least, the demand-side slowdown which is expected.

\section{RENTAL GROWTH OUTLOOK}

Over the last 12 months, according to IPD, ${ }^{7}$ the retail warehouse market has seen improving rental growth (but some slowdown is now evident over the last two months), higher than in any other sector, although GVA Grimley's figures for prime rental growth show a continuing weakening of rental growth over the last three years. ${ }^{8}$ Investors have shown their confidence in the sector in no uncertain way, with a huge level of purchases. With restrictive planning policies affecting out-of-centre development, the outlook for rental growth looks positive.

The demand-side slowdown expected over the next few years will, however, outweigh the supply-side constraints. The latest forecasts, therefore, show rental growth weakening in the latter half of this year, achieving 3 per cent for the year as a whole, compared to 5.4 per cent in 2002. ${ }^{9}$ The author's company expects weaker rental growth in 2004 and 2005 (1-2 per cent per annum), and then an increase to 4.5 per cent in 2007 . Nevertheless, despite this shortterm weakening, the outlook is still better than for other sectors.

\section{THE INVESTMENT MARKET}

As mentioned briefly at the start of this paper, investment in retail warehouses has increased significantly in recent years as the supply/ demand imbalance and superior rental growth referred to earlier have become more evident. This is illustrated in Figure 5, which shows both the actual net annual investment in retail warehouses since 1986 and its proportion of total net annual investment. It is the latter figures which are the most telling, showing the attraction of retail warehouse investment in the last two years particularly. This high share of investment is even more significant when it is remembered that retail warehouses are merely one of three subsets of the retail sector.

This growing attraction of retail warehouses as an investment can be seen in Figure 6, both in the absolute downward shift in yields over the last ten years and also in the relative downward movement compared with the all-property average. This gap has widened noticeably in recent years. This reflects not just the perceived supply/demand imbalance in this sector, caused by strong demand from retailers wanting larger floorplates and lower costs (rents) and restricted supply, but also due to the maturity and increasing size of this relatively new market in the 1990s. 


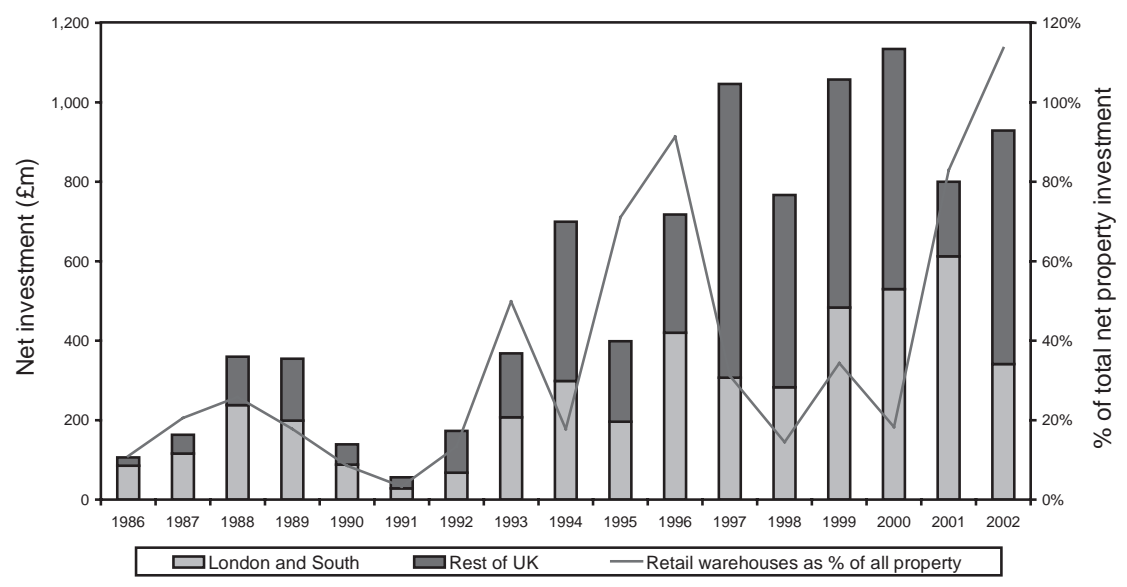

Source: IPD Annual Index

Figure 5: Net investment in retail warehouses

With relatively strong rental growth and a downward movement in yields, it is not surprising that the retail warehouse sector has outperformed the overall IPD all-property index in recent years. Returns from retail warehouses have averaged 12.3 per cent per annum over the last five years, compared with 10.3 per cent for all retail and 10.6 per cent for all property. 2002 saw an even greater outperformance, with a return of 17.4 per cent for retail warehouses compared with 14.1 per cent for all retail and just 9.7 per cent for all property (with performance dragged down by the poorly performing London and South East office markets).

The latest IPD monthly index figures ${ }^{10}$ show this divergence

High returns not sustainable widening further in the first half of 2003, but retail warehouse returns of 17.8 per cent per annum (May 2003) are not sustainable, with weaker retail expenditure growth and weaker rental growth

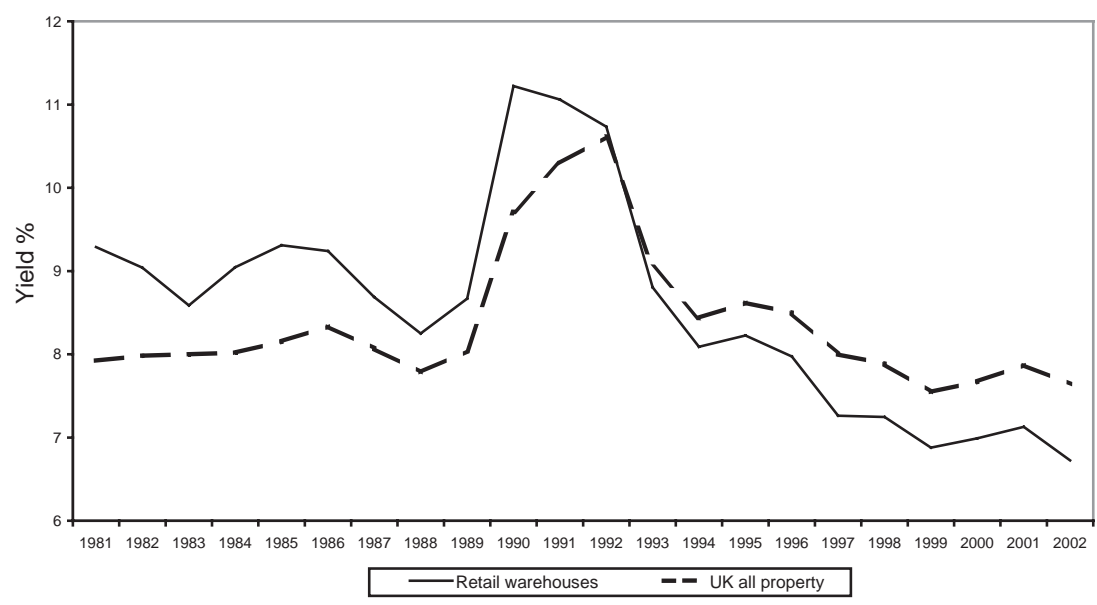

Source: IPD Annual Index

Figure 6: Commercial property - Equivalent yields 
expected. With higher interest rates expected in 2004 and a rebalancing of the economy likely, it is expected that other property sectors will be perceived to show greater value and retail warehouse returns will weaken. Nevertheless, this is all relative, and returns in line with the all-property average, close to 10 per cent per annum over the next five years, should be little different from the average achieved over the last five years, although noticeably lower than the current levels of returns.

\section{CONCLUSIONS}

The retail warehouse market is underpinned by strong fundamentals - the occupational supply/demand imbalance. Demand is likely to weaken in the short term as retail expenditure growth weakens and higher retail warehouse rents on some schemes act as a brake. The imbalance will lessen in the short term, but it is hard to imagine a major change in national planning policy, so supply is likely to remain restricted. The imbalance looks like being a permanent feature of the market, although probably less than it has been for two reasons. The narrowing of the retail difference between town centres and retail warehouses will lessen the perceived advantages of retail warehouses for occupiers and there will probably be some slight easing of the restrictive planning policies relating to edge/out-of-centre bulky goods retail warehouse development.

This scenario, if it proves correct, would inevitably feed through into the investment market, which has seen very strong demandreduced yields and high returns in recent years. This outperformance is likely to moderate as rental growth slows and the downward yield movement ends. Returns in line with the allproperty average seem likely in 2004-2007.

\section{References}

1. IPD UK Monthly Index (2003) June, www.ipdindex.co.uk.

2. IPD UK Annual Index (2003) www.idpindex.co.uk.

3. The UK Property Investors Bulletin (2003) Property Data, June.

4. IPD UK Annual Index, ref. 2 above; GVA Grimley database (unpublished).

5. Experian Business Strategies (2003) Regional Planning Service, Vol. 2, Spring.

6. Department of Trade and Industry (2003) 'New construction orders', statistical press releases (various).

7. IPD (2003) MIPS - Market Information for Portfolio Strategy, June.

8. GVA Grimley, ref. 4 above.

9. GVA Grimley (2003) June, unpublished.

10. IPD, ref. 7 above. 